\title{
THE TRANSFORMATIONAL LEADERSHIP OF THE FEMALE LEADER IN PESANTREN
}

\author{
EKA ADNI RAHAYU* AND NAHIYAH JAIDI FARAZ \\ Universitas Negeri Yogyakarta
}

\section{Abstract}

This study aims to reveal three leadership elements of the female leader at Nurul Ummah Putri Islamic Boarding School (PPNU-Pi) by exploring the nature of leadership, the decision-making process, and the leadership style. This study is grounded on qualitative research using a case study approach through interviews, observation, and documentation. This study highlights that nyai as the female leader at PPNU-Pi possesses a firm, caring, intelligent, straightforward, communicative, and optimistic nature of leadership. The decision-making process at PPNU-Pi is conducted in a relatively modern way. It starts with identifying the problem. Then, it will be followed by looking for alternative solutions. After selecting alternatives which are conducted together with the female leader, they will implement the solution. After applying the solution, there is a trial period to see how effective the solution has been implemented. Finally, this study discusses the implementation of female leader leadership in PPNU-Pi, which represents essential characteristics of transformational leadership such as female leader as an ideal influence, inspirational and motivational leader, and intellectual stimulators.

Penelitian ini bertujuan untuk mengungkapkan tiga elemen kepemimpinan pengasub perempuan di Pondok Pesantren Nurul Ummah Putri (PPNU-Pi) dengan meneliti sifat kepemimpinan,

\footnotetext{
* Corresponding author: Jl. Colombo No.1, Karang Malang, Caturtunggal, Kec. Depok, Kabupaten Sleman, Daerah Istimewa Yogyakarta 55281. Email: ekaadnirahayu@gmail.com.
} 
proses pengambilan keputusan yang dilakukan oleh pengasub perempuan, dan kepemimpinan transformatif pengasub perempuan. Penelitian ini merupakan penelitian kualitatif dengan menggunakan pendekatan studi kasus yang dilakukan melalui wawancara, observasi, dan dokumentasi, Hasil penelitian menggarisbawahi bahwa pengasuh perempuan di PPNU-Pi memiliki sifat yang tegas, peduli, cerdas, sederhana, komunikatif, dan optimis. Proses pengambilan keputusan di PPNU-Pi dilakukan relative modern dengan diawali dari mengidentifikasi masalah, dilanjutkan dengan pencarian alternatif solusi, pemilihan alternatif bersama dengan pengasub, penerapan solusi, setelah penerapan solusi ada masa coba untuk melihat seberapa efektif solusi yang sudah diterapkan. Yang terakhir, pelaksanaan kepemimpinan pengasub perempuan di PPNU-Pi menerapkan ciri penting dalam kepemimpinan transformasional yang meliputi pengarub ideal, motivasi inspirasional, stimulasi intelektual, pertimbangan individual.

Keywords: female leader; pesantren; transformational leadership.

\section{Introduction}

Leadership is an essential element in both formal and informal organizations. The progression of an organization relies on leadership. Suharsaputra (2012) discusses leadership as the ability to influence someone to achieve the goals set within the organization. Additionaly, Hermino (2014) explains leadership in a general sense by showing the process of activities in leading, providing guidance, controlling behavior, feelings, and attitudes towards others. Turney and Bishop (2004) also express their opinions regarding the notion of leadership as a group process carried out by someone in managing and inspiring some jobs to achieve organizational goals through the application of management techniques.

The issue of women's leadership has remained contentious in some countries, including Indonesia. Some communities are 
in favor of women as leaders, while some others disagree. Bass and Riggio (2006), and Klenke (2017) argue that women who could potentially be leaders seem to have no barriers, but the actual leadership seats have been quite challenging for women. Women should have the right to be leaders at every level. Historically, in Indonesia some women were involved in the war with the same responsibilities as men.

However, based on the Human Development Report, different data can be presented.

Diagram 1

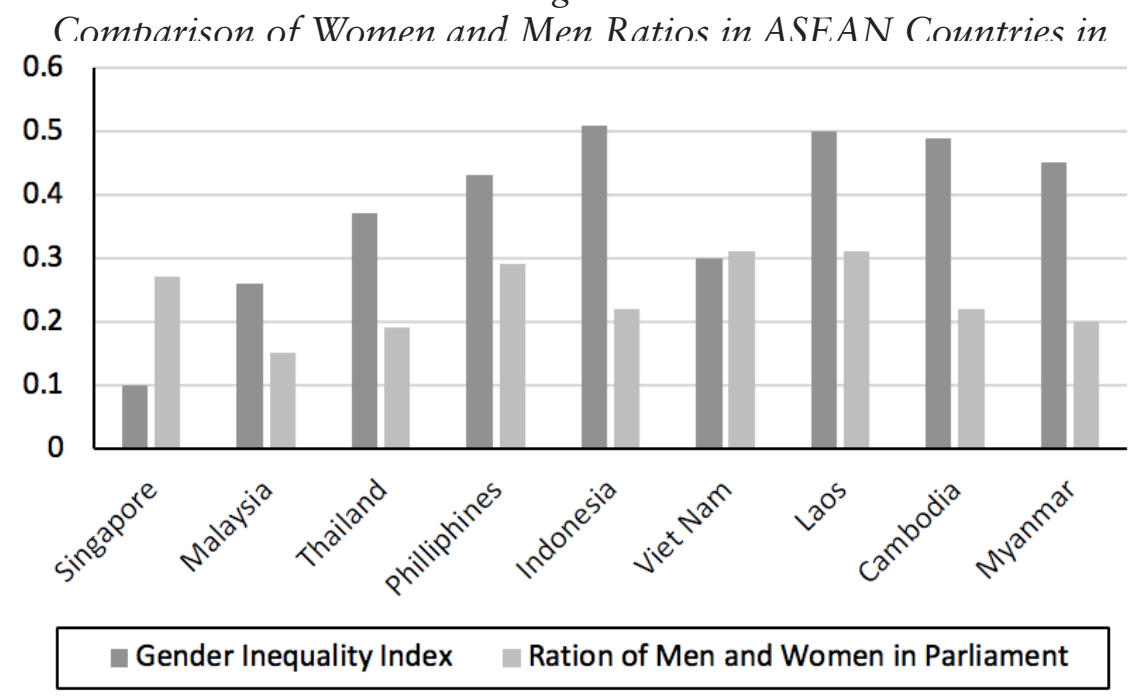

The data shows that ASEAN countries, especially Indonesia, Laos, and Cambodia, still experience gender inequality. The role of women in parliament still lacks compared to men. In addition to gender inequality, the data above indicates that men are better suited to be leaders while women are not. Women are still primarily considered as housewives in some ASEAN countries. In light of this discussion, Fauzia (2004) argues:

Gender inequality is a reflection of society due to the definition and standardization of different gender roles 
among men and women towards the division of labour according to gender categories and ideological assumptions. With the strength of patriarchal gender ideology, men and women do not have the freedom to determine the choice of social, cultural, and legal roles.

The paradigm of the division of labour between men and women eventually leads to indiscretions if women carry out the work that is usually more appropriate for men. For example, women are considered unsuitable to be a tire repairman, a pedicab driver, and as a community leader. Nowadays, there has been evidence showing the development of women's movement in Indonesia. It can be seen from some women figures in Indonesia who occupy important positions. For example, Megawati Soekarno Putri is the fifth Indonesian president; Susi Pudjiastuti is the maritime minister; Sri Mulyani is the minister of finance; Nila F. Moeloek is the minister of health.

This study aims to unpack the female leadership in pesantren through the lens of the female leader. ${ }^{2}$ The nature of leadership in pesantren is not much different from the leadership in other formal institutions. The discussion of leadership in pesantren is usually centered on the figure of Kiai (the head of pesantren); therefore, the leadership of women in pesantren remains unexplored. Women in the Kiai's family, such as wives and children, have a significant role in managing the pesantren. Furthermore, Srimulyani has observed the lives of women in the pesantren, their representation, and leadership. In particular, their position as a prominent female figure in pesantren. The existence of women's leadership in the pesantren is a result of negotiations. The form of negotiation is to continue to play a role in the pesantren, although structurally, it is often not counted as

\footnotetext{
${ }^{2}$ The female leader is employed here for a concept of "pengasuh perempuan" of a pesantren. Here, the female leader will be used interchangeably with "nyai".
} 
the leadership of the pesantren. Srimulyani (2012) explains that the lives of women in pesantren, their agency, and leadership are quite complicated. Observation of their lives and agency has presented something beyond the "gender bias" limitations. Although pesantren is attached to patriarchal religious values that emphasize the dichotomy of public and private domains, the life of some female leaders has indeed illustrated how these dichotomized domains could be "negotiated".

Similar to other pesantren, Pesantren Nurul Ummah Putri (PPNU-Pi) is led by a Kyai. In this Pesantren, however, the leadership is distributed to other religious figures. Every activity, regulation, and matters related to the pesantren are more often discussed and decided by nyai (Kiai's wife). The emergence of nyai as the leader of pesantren, who takes quite a dominant role within pesantren, raises questions about how leadership in the pesantren works and what style the female leader employed in her leadership. Faraz (2013) has found that men generally display leadership more transactional than women. Conversely, women in leadership are more likely to present a transformational style than men.

Kenneth Nowack in Wirawan (2013) also researches the differences between men and women leadership. The study indicates that women employs more participatory and transformational leadership compared to men. They also suggest that the oxytocin hormone causes differences in women's leadership to be more transformational while men are more transactional.

Based on these discussions, this study aims to unpack female leadership at Pesantren Nurul Ummah. This study explores the notion of women transformational leadership through the decision-making process carried out by nyai in pesantren.

This study used a qualitative research method through a case study. Sukmadinata (2013) argues that qualitative research is a 
research aimed at describing and analyzing phenomena, events, social activities, attitudes, beliefs, perceptions, thoughts of individuals individually, or in groups. This study employs various data collection methods, such as interviews, observations, and documentation. The data source of this research is the female leader (nyai) of the pesantren, along with administrators and students.

\section{Result}

The character of the Female Leader at Nurul Ummah Putri Islamic Boarding School Kotagede (PPNU-Pi)

One's character may influence the leadership style. According to Bohlin, Farmer, and Ryan, as quoted in Sudaryono (2014), character is interpreted as a special sign or pattern of behavior from someone. Based on the results of the study, the characters of pesantren's female leader are discussed below.

\section{Decisive}

Based on the data from the field, this study found the decisive role of the female leader. Both the board members and the students explained that nyai has firmness in carrying out leadership. When interviewed, the female leader explained that they were a firm figure, especially in terms of applying religious law and regulations in pesantren. The female leader revealed, that firmness was indeed needed, especially in terms of the application of religious and regulation laws, there was no tolerance when carrying out religious law.

NM conveyed the same thing regarding the firmness of the female leader. NM said that the female leader had a firm character that could be seen from the way the female leader speaks, applies laws and regulations in the pesantren. The female leader does not discriminate when giving punishment; for students or 
administrators, if they violate rules, consequences apply to all pesantren's members regardless of their position.

The same statement was also delivered by one of the ARA students who stated that the female leader's tone of the speech was quite loud and firm so that students who did not understand would think the female leader was angry. The assertiveness of the female leader in leading pesantren is recognized by the female leader themselves, administrators, and students. This assertiveness influences the students to be consistent in upholding religious law and pesantren regulations.

\section{Caring}

The female leader's figure, in addition to having a firm character, also put great attention on students. In the interview, NM conveyed that the female leader showed a caring attitude in daily interaction with students. The female leader always maintain communication by always deliberating when deciding cases. Optimistic also becomes the character of the female leader in carrying out leadership.

The supervisor of the equipment division also said that the female leader is a figure who cares for anyone. NK conveyed that the female leader donated salaries to cleaners who cleaned the garbage, the female leader also provided additional groceries such as oil and rice to them. Not infrequently the female leader also spends their money to give to garbage cleaners as extra money for their children's snacks.

The female leader's form of care was also seen when the researcher conducted an observation. The female leader supported junior students and senior high school students wanting to take the national exam. Based on the results of interviews and observations, it can be seen that the female leader has a concern, both for students and other people who are not students. 


\section{Smart}

The female leader is not a graduate from a well-known tertiary institution, but a female leader is an intelligent person. The female leader has memorized 30 juz Al-Quran at a young age at the same time she also served as the chairman of the Jogja City Muslimat Organization for up to 3 periods. According to NK, one of the PPNU-Pi administrators, the "Nyai" is the head of the Muslimat for three periods not because she nominated herself, but the Muslimat members agreed to elect her for up to three periods. This is also proof that she has intelligence in leading an organization.

The student with the initials NI said the "Nyai" always included an argument or basis legal when answering questions. The language used by the female leader also reflects somebody who is intelligent and has many insights.

During a visit to the house of the "Nyai", there is indeed a huge collection of yellow books (Kitab Kuning) and books that show that the female leader studies hard and reads a lot. A aantri (with the initials ARA) also said that the "Nyai" was able to study books for the upper-class Madrasa whose books had entered a difficult stage and needed a deep understanding.

\section{Simple}

The female leader's simplicity is reflected in the way she dresses. When visiting the Nyai's house, she was dressed in a negligee of mothers in general with a rectangular headscarf that was only tied loosely on the neck. The Nyai admitted that she rarely bought new clothes because the old clothes were still good and decent. Besides, many alumni bring clothes, gloves, or sandals as gift when they come to visit.

The simplicity of the female leader is not only in terms of clothing, but also in the food consumed. The food is general 
people's food, not fancy food as presented in luxury restaurants. A manager with the initials NK said that the rice and vegetables eaten by the female leader are also the same as the rice and vegetables that are allotted for santri. Her Santri with the initials ARA also acknowledged the simplicity of the "Nyai". ARA said the simplicity of the female leader was obvious from the clothes worn.

\section{Communicative}

Leadership requires excellent communication. Communication is one of the essential skills for leaders. It becomes the primary way to provide direction and gives tasks to subordinates. Excellent communication will produce good responses from their followers. One of the administrators, NK, said that the "Nyai" had smooth communication with the management. Every critical task that requires the female leader's decision is always communicated with all committees. The involvement of other committees is mainly done when the female leader has to decide a matter related to the interests of the people, especially the students. The female leader will usually call the committee regarding a particular issue. In the case of building a pesantren facility, for instance, the "Nyai" will call the management of the facility division for discussion. The female leader also remembers all the names of the committee, which makes it easier to coordinate.

The figure of the female leader is also known with straightforward communication. The tempo or the speed of talking of the "Nyai" is also fast, indicating that she was a firm figure. Although she was busy, the "Nyai" was willing to be interviewed in a written way. It can be seen that the female leader is not the type of a leader who likes to make small talk. She prefers to working hard to ensure that the communication is well distributed. 


\section{EKA ADNI RAHAYU AND NAHIYAH JAIDI FARAZ}

Based on information from the NK, it turns out that the female leader also has a strong memory by knowing the names of the coordinators of each boarding school division. This makes it easier to communicate because the "Nyai" can articulate the problems that occur with the person in charge of each division.

\section{Optimistic}

All hopes and intentions are important for the benefit of students. Students need to own an optimistic attitude during their studies. Nyai Barokah, as the female leader, conveyed that hope is good and noble, and it must be accompanied with optimism so that all can be reached.

The chairperson of PPNU-Pi said that for the benefit of the students, the female leader struggled very hard, sacrificing a lot of things both material, energy, time. It is also a form of female leader's optimism that as long as there are effort and struggle, there will definitely be a way and finally the students can find success.

One of the administrators of the equipment division also said the same thing. Sister NK noted that when the female leader had the intention of land acquisition to the west of the pesantren, the female leader would unceasingly invite all students and administrators to continue to pray specifically regularly for the ease of land acquisition. The female leader feels optimistic and believes that by continuing to pray, coupled with effort, what becomes can be immediately wish granted.

Based on the results of the interview above, it can be concluded that the female leader of PPNU-Pi does indeed has a strong belief when having a purpose, especially the intentions or expectations related to the benefit of many students. 


\section{Decision Making Process of Nurul Ummah Putri Islamic Board- ing School for Female}

Taking decisions is one of the important tasks of the female leader. How the female leader analyzes and observes the happening problems also reflects the intelligence of the female leader. The existence of a problem is a manifestation of a mismatch between expectations and reality, so it requires a way out or a solution to deal with the issues that occur. The following are the results from the field regarding the decision making the process of the female leader at PPNU-Pi.

NM explained that decision making from the female leader was inseparable from the role of the boarding school administrators. The board, consisting of the female leader and administrators, will first discuss the problems in the pesantren through a monthly plenary meeting. The plenary session is a large meeting of the management of all the divisions. They include the security divisions of PPNU-Pi, hygiene and health division, education division, secretary, treasurer, equipment division, cooperative division, public relations division, and three representatives from the management of each complex, and also the management of pesantren. Each division will explain and explain the progress and problems experienced in turn. After exposure to the problem, all the administrators analyzed the cause and tried to find a solution. After finding a solution, the relevant management will convey to the female leader to be discussed with her and decide which solution will be taken.

The results of the interviews show that the problems that occur will be first discussed and some solutions are sought by the new management and then will be submitted to the female leader to determine which solution will be used. Then from the author, the question arises what if the problem is urgent and needs a solution immediately. It turned out that the management 
also used to hold internal meetings with their foreign exchange. This is to anticipate problems that require a solution immediately. The female leader will hold a meeting as soon as possible and immediately found a solution. The interview also showed that not all problems were addressed to the female leader. The board will try and deliberate about finding a solution first. It is intended that the management can help the female leader and can ease the burden on the female leader. In addition, the female leader is busy and often travel out of town, so that the caretaker must be able to represent her and ensure all activities in the pesantren run as they should even though the female leader is not in place.

The solution that is produced during the plenary meeting and has been favored by the female leader will then be run. After running, there will be a monitoring period. The monitoring period means the time to observe the solutions that have been implemented, whether successful or not or still need new solutions. Usually, problems that require monitoring are problems that can be solved by requiring a long period. For example, security issues related to night patrols for female students to maintain the security of pesantren. patrols are Nightcarried out alternately each room. It turned out that the santri putri were enthusiastic about holding a night watch because they were permitted while watching a film accompanied by snacks and coffee - the enthusiasm of female students to circulate patrolling shows that there is a security solution that works well.

The female leader also turns out to be the person who upholds deliberation in setting decisions. The female leader will first consult with the board before setting. Mrs. CH said that every case related to the benefit of the female leader always decides by deliberation. Even the female leader always asks whether the problem being faced has been discussed beforehand with other administrators. This shows that the female leader is democratic 
and upholds the value of deliberation. The good thing is that a female leader is someone who knows the caretaker well. When the female leader wants to talk about problems regarding pesantren security, she will call the name of the pesantren security coordination. If he wants to talk about development issues, he calls the board manager. Said the NM sister.

Based on some explanations and the results of the interview above, it can be concluded that the decision making of the female leader in PPNU-Pi is assisted by all levels of the management. This aims to provide convenience for the female leader and as a form of business of the administrators to reduce their workload and burden of thought. It is also known that decision making begins with problems that occur, which are then brought to the plenary meeting forum once a month. The plenary meeting with the entire management board resulted in several alternative solutions which were then reported, discussed, and decided with the female leader. The solution that has been chosen is then applied, and after it is implemented there will be a trial period of several months. This trial period is useful to find out how effective the solution has been implemented. If it is still not effective, another solution will be found.

Implementation of Transformation Leadership for Women Leader at Nurul Ummah Putri Islamic Boarding School

Description of the results of this study was obtained from the field and elaborated in accordance with the sub aspects that were made previously. The following are descriptions of the results of research that have been carried out:

\section{Ideal influence}

On the sub-aspect of the ideal influence has been divided into two indicators, while the indicators are: 


\section{Indicted/respected}

Leadership in Islamic Boarding School Nurul Ummah Putri (PPNU-Pi) held by KH Munir Syafaat and Nyai H. Barokah Nawawi, but for the main leadership is held by Nyai Barokah Nawawi, both from the management and boarding school management. This is in accordance with the statement of the chairperson of PPNU-Pi, NM. The reason for caring held by Nyai Barokah is because from the beginning the establishment of the pesantren putri, all of its management was handed over by Nyai Barokah. The female pesantren was first established by Nyai Barokah together with Kiai Asyhari Marzuqi, who then managed the female santri entirely to be handed over to Nyai Barokah. Meanwhile, Kiai Asyhari himself managed the first male santri. Then after changing care, the Islamic boarding school for management and management remained held by Nyai Barokah.

Her position as a female leader, Nyai Barokah was administered by the management and students. Whatever is the command of the female leader is always carried out by the students and administrators. The administrators also try to carry out what is a mandate for them with as much as they can. This is consistent with the results of interviews with administrators and students. Sister ARA and sister NM are always trying to revere and carry out what the female leader offered. For them the female leader is the figure of the second parent after their biological parent. As long as they study at pesantren, their female leader is their parents. So as much as possible they are always reverent the female leader.

Nyai Barokah, when asked about the injustice of the students and administrators, answered that in general the students and administrators were quite respectful of her. She also said that however, they are busy at school, each student and administrator could carry out the duties of pesantren, studying the 
Islamic sciences, worship, associate, carry out the rules and regulations of the pesantren well.

The results of observations found in the field also support the results of interviews with informants. It is found in the field that students who want to study the Qur'an never go to the female leader's table while standing, but walking on their knees. When completing the study, the students leave the female leader's table not standing and facing away from the female leader, but in a walking condition with both knees and walking back off. When they met the "Nyai" on the street, students did not dare go ahead of him. They preferred to stop first. This is part of the students' respect for the female leader.

The results in the field were also found, that not all students have a strict adherence to the female leader, because there are still students who violate the "dawub"/female leader's advice. This is proven in the field, there are still some santri undergo punishment for breaking the rules of the Islamic boarding school both punishments related to security division and the educational division.

\section{Requested approval for each decision or activity}

The activities in the Nurul Ummah Putri Islamic Boarding School are very diverse, ranging from routine activities to incidental activities both organized by the educational division and from the committee. The management and the committee are responsible for running the event or activity. The implementation of the activity or event is not merely held and run smoothly, but the management and the committee had previously requested approval from the female leader.

Nyai Barokah herself stated that almost all activities in the pesantren were with her approval. This is consistent with the results of interviews with students of ARA who acted as the organizers of the haul event, ARA said that in the event the commit- 
tee will not move unless it has been approved by a female leader, although usually, the female leader give freedom the committee to run the committee, the committee remains seek the approval and opinion of a female leader.

The manager who acts as the chairperson also states the same thing when asked with a similar question, that when the board has ideas about new activities, or solutions to problems that occur, the board never relinquishes the female leader. In a sense, the caretaker always conveys to the female leader and discuss with her. The former PPNU-Pi CH chairperson also stated that he always requests the female leader's approval when asked about her approval in every decision and activity.

The results of observations in the field also support the results of interviews conducted with several informants. In the field, it was found during the preparation of the 14th KH Asyhari Marzuqi's Haul Ceremony, the committee and the board managers meet the female leader to ask for opinions or approval regarding the date of the event determination, the various series of events, logistics needs, the need for equipment, and several other needs. It was also found that the committee security concerned about students who often committed violations severe enough to then be given appropriate actions or policies based on the deliberations of the management and the female leader, as well as discussing the work program of the security management regarding the construction of fences in the parking area of the lodge for security.

\section{Inspiring motivation}

In the sub-aspects of inspirational motivation in it are divided into two indicators, as for the indicators, namely: 


\section{Providing challenges in work}

Providing challenges in carrying out tasks or commands to subordinates will provide their learning. The challenges will make them learn and try seriously in carrying out the duties and commands of the leadership. Not much different from the responsibilities and orders given by a female leader to the boarding school administrators. The challenge will make the administrators learn more about many things and will be able to complete the tasks and commands of the female leader well.

Nyai Barokah herself said that she did indeed provide a challenge for the management when they carried out the duties and orders from the female leader which of course the challenge was adapted to the capabilities and conditions that exist. This indicates that the female leader understands and considers the capabilities of the management because she has adjusted to the existing conditions and conditions. Nyai Barokah also stated that she gave challenges to the management through many things, especially through communication, direction, discussion and evaluation.

For the managers themselves, the taste of the challenges that they receive perceived different each individual. This is because the burden of each management division is different. For the Chairperson of PPNU-Pi, the challenge perceived is when the female leader's time is collided with a schedule of lectures or important activities outside the dormitory so that she demands that she can manage his time as effectively and effectively as possible.

Another challenge that is often faced by administrators is when what is offered by the female leader is reversed with what is expected by the students. The administrators must be able to convey what the female leader offered to the students is in a language that is acceptable to the students. The caretakers also 
sometimes have difficulty in uniting the female leader's "dawuh" (decision) with the wishes of students. This was not only felt by Ms. NM, but the general chairperson of the previous period, Mrs. $\mathrm{CH}$ also experienced the same thing.

The challenges that they both experienced were obstacles to communicating and uniting the female leader's "dawuh" with the desire of the santri. Both administrators experienced problems or experienced the same challenge of aligning the female leader's desires with the wishes of students.

\section{Communicating important goals to be achieved}

Communication is an essential element an organization. With the excellence communication, everything can run smoothly, and problems can be resolved. Nyai Barokah is accustomed to sharing or communicating what are important objectives in pesantren, problems encountered in the management of pesantren and santri, and all matters relating to pesantren. Vice versa, when the board also has an idea, or a new work program will meet the female leader to ask her agreement. Communication that is established between the female leader and managers is well established and intense.

The female leader also understands with whom and with which division she must communicate important matters and goals. This it even makes it easier to achieve a purpose or intent, because she directly communicates with the relevant division. The interview shows that the female leader has a high awareness of the importance of communication for the continuity and interests of pesantren, as well as for achieving the benefit and goals to be achieved.

The results of interviews with several informants above are also supported by the results of observations by researchers in the field. In the field it has been found, that the female leader does establishes excellent communication with the administra- 
tors, especially regarding matters relating to boarding schools. It is also found that the female leader calls administrators to discuss something related to the interests of boarding schools. Usually, the female leader will also summon the administrator for the problem to be discussed. Like when before the Haul Ceremony was held, the female leader often called Haul committee to discuss matters relating to the performance of Haul Ceremony.

\section{Intellectual stimulation}

In the sub-aspects of intellectual stimulation in it are divided into two indicators, while the indicators are:

\section{Practicing Innovation or New Ideas at Work}

One of the transformational leader characters is a leader who practices innovation or new ideas in doing work. Innovation or new ideas are indeed necessary. With the great innovation, the organization could develop in accordance with the demands of the times and adapt to the needs of the moment. Ms. CH conveyed, Nyai Barokah, as a leader in PPNU-Pi, was innovative and applied new ideas in carrying out her leadership. She tried to find out how and how to solve if he finds a found a problem or found a new policy that would still have problems. The results of interviews with Ms. NM also stated the same thing about the innovation of Nyai Barokah Nawawi. Innovative and trying to find new ideas in running the leadership then made Nyai Barokah a female leader who thought about the benefit and progress of students, administrators, and boarding schools.

The observations in the field also show that the female leader do have an innovative attitude in carrying out their leadership. She tried to find ways how problems that exist in boarding schools can be resolved, or activities in boarding schools can run well. For example, in PPNU-Pi on Friday night, all studies 
were closed, but the female leader thought about how to make the santri holiday even though a day can be useful and enjoyable, so the female leader together with the management made policy, that Thursday night when holidays are filled with events that support students. The usual programs on Thursday night are the four language speeches, muqoddaman, al- barzanji, and simtutdhuror. The programs are carried out in such a manner every Thursday night.

\section{Exploring new ideas and creative solutions of the students}

The female leader, in addition to providing a solution on the board, also explored the creativity of the board and his students. This is done as a form of deliberation so that the decisions and regulations that are made provide the common good. The board is a connection between the female leader in carrying out boarding school management. Therefore the board will also take part in making policies or regulations at the boarding school even though later to decide the policy remains with the female leader. The contribution given to the administrators is one of the forms in the form of excavating ideas and ideas carried out by the female leader. The caretaker himself said that exploring the ideas and creativity of the students was important to obtain mutual benefit because humans were indeed created, they should be sharpening, caring, and caring.

The results of interviews with the Chairperson of PPNU-Pi stated that the female leader is a figure who provides opportunities for students to learn and understand. Not only learning about the yellow book, but the female leader also hopes students and administrators to learn how to organize and coordinate through courtesy at events in pesantren, learn to find solutions to problems being faced during the implementation of activities, and most importantly learn to socialize and socialize even within the scope of small. From there, it will emerge new thoughts 
and ideas because they are honed continuously by obstacles so they can find solutions.

Based on the results of interviews, exploring ideas and creativity from administrators and students is usually done by Nyai Barokah because it is considered capable of bringing benefit and goodness to be together. Interviews with several informants also in line with the results of field observations. The researcher found that when the madrasah's semester exams were finished, the pesantren held a haflah event to commemorate the pesantren's birthday. The committee of events is formed by the board and authorized by the female leader. The entire committee worked hard in making the event a success after the committee had been established, the caretakers gave up all the events, including activities to be held in the event. The committee also created ideas and creativity to create a series of activities that were interesting and as exciting as possible. After the plan is activity formed, it is recommended to the female leader, after obtaining an ACC, a series of activity plans are carried out.

The results of these observations indicate that the female leader do provide opportunities for their students to explore their potential and creative ideas, provide space and facilities for students to express their thoughts and creativity.

\section{Adapted considerations}

In the sub-aspects of individual considerations in it are divided into two indicators, while the indicators are:

\section{Give awards to students who excel}

Giving awards to students, employees, teachers, or employees who excel will provide their motivation. Because what they have worked for and those they strive to feel more valued. Giving awards is also a form of appreciation and can also be a motivation for other parties who have not yet received an award. 
The award also varies both material and non-material, because the award is not merely in the form of gifts, rewards, money, or the form of other objects.

The female leader, Nyai Barokah, conveys, that she could not give an award to the students and administrators who excel in material form. She also said that the form of appreciation that he gave to students or administrators who excel in the form of appreciation and spirit, awards in the form of prayers and feelings that can only be felt by specific individuals concerned.

The board also gave the same statement when interviewed. The caretaker said that Nyai did indeed provide an award to the students who excelled even though the form of the award given was not in the form of material. The Chairperson of PPNU-Pi in the period previous, Mrs. $\mathrm{CH}$, also said that the female leader would be more direct when there were students who were diligent or achievers and the female leader would pay attention. Although giving more attention to students who are diligent and achievers, it does not mean that the female leader is discriminating towards their students. Usually, the female leader will be more direct so that the achievements of the students can be more useful. For example, students who are close to or memorizing have completed memorizing the Koran will usually often get advice to continue to add enthusiasm and increase the frequency of memorizing rote. The female leader will regularly monitor and test the memorization of the students. This is a form of attention and form of the female leader appreciation for students who have certain achievements.

Based on interviews with several sources it can be known, that as a female leader, Mrs. Nyai Barokah is a person who appreciates the achievements of her santri, and did not hesitate to give appreciation to students who excel. 
Field observations also show that the female leader does not reward their students with forms material, but the female leader gives appreciation and expressions of pride towards their students. Seen during the peak night of Haflah, Graduation Madrasah, and the distribution of care report cards congratulated the students on the graduation and expressed their pride to all graduates because this year was the most graduated from previous years. Provision of shahadah as proof of exemplary santri was also carried out. For students who have never been absent from the Qur'anic sorogan, worshipers and who never play truant from the pesantren will be given the title of exemplary santri. During the evening distribution of report and graduation, the santri exemplary will be summoned and given shahāda directly by the female leader. The female leader will give hugs and congratulations, and students can take pictures together with the female leader. When this happens, many students cry out and want the same thing to happen to them.

\section{Providing learning opportunities for every student}

Santri with the initials ARA states that when teaching or mastering the Quran, the female leader does not discriminate. Only students who still cannot read fluently will be given extra hours to provide by the certain ustadha that has been appointed. The aim is to catch up and accelerate the smoothness of the Qur'an. In the observation it was also known, that all students whether administrators or not waiting in line to deposit memorization to the female leader, all in accordance with the order of the queue and all given the same service and treatment when reciting. All students who recite when wrong are rebuked and guided on the incorrect reading. There is no difference in treatment between one santri and another santri. 


\section{Discussion}

\section{Character of Female Leader in PPNU-Pi}

Character is an underlying value that builds a person's personality, is formed both due to the influence of heredity and environmental influences, which distinguishes it from others, and manifests in his attitudes and behavior in life daily (Samani and Hariyanto 2012, 237). In terms of character, the female leader of PPNU-Pi has a number of characters that are felt by students and administrators who become female leader's styles in leading pesantren. The character of a female leader who is strict in enforcing pesantren regulations is also religious rules indiscriminately. The way he spoke also showed that he had firmness and intelligence.

When viewed from the character of the female leader, he has a masculine side that is reflected in the firmness and form of communication that is straightforward. However, as a female leader caring attitude, women cannot be covered up. Having cared for other people is the character of the female leader of PPNU-Pi. Want to give help to others who are in need. The female leader's care is not only aimed at his students, but also to others, even though he only works as a garbage cleaner at the pesantren. In accordance with that described Narwanti (2012, $64)$, social care is an attitude and action that means to always eager assisting others in need.

Other characters the female leader has, besides caring, is smart. The female leader's intelligence was also seen, both because he was indeed a teacher at the madrasa diniyah and capable of writing books for the upper class, and he was a leader. Her leadership had also been up to 3 periods in the Muslimat organization. Sudaryono $(2014,35)$ explains intelligence is the capacity to understand the world, reason and use resources effectively when facing challenges. 
Simple is also one of the characters of the female leader. Simple in terms of clothing and terms of food has become a habit of the female leader. The simple character of a female leader is in accordance with what was delivered by Wijaya $(2014,117)$ that a simple attitude is a person's habit of behaving according to his needs and abilities. Simple can also mean not excessive or does not contain luxury.

A good leader is a reliable communicator. Most of the time used by a leader is to communicate, both internal and external. Leaders' activities are carried out through two-way communication, both verbal and nonverbal communication (Sudaryono 2014, 34). The steps of the female leader and the caretaker have been right, both from the female leader and the caretaker both maintain excellent communication with each other. Even though the management has a feeling of being reluctant and afraid that they will make mistakes, communication continues to run well.

An optimistic attitude is also one of the characteristics of the female leader. Optimistic also means having a strong belief in hope or desire. An attitude optimistic usually will give birth to a serious effort to achieve what the hopes and desires. The sense of optimism in caring in the pesantren is in line with the opinion expressed by Seligman (in Ghufron and Risnawita 2011, 96) conveying optimism is an overall, view seeing good things, positive thinking, and easy to give meaning to individuals who are optimistic able to produce something better than the past, trying to keep up trying again if it fails. The female leader also has a great effort, sacrifice both in material and non-material terms to realize expectations.

All the characters or personalities in a leader figure are also explained by Hadari Nawawi (1998, 84-90) which states that there are specific requirements personality or character that 
must be possessed by a leader to truly become a role model and be able to carry out leadership well, these characters include:

a. Have good intelligence and intelligence

b. Self-confidence and membership

c. Proficient, communicative and suave

d. Creative, full of initiative and have the will to progress and develop for the better

e. An influential and authoritative organization

f. Having expertise or skills in the field

g. Like to help, like to give directions and can punish firmly, consistently, and wisely

h. Having emotional stability and patience

i. Have a spirit of dedication and high loyalty

j. Dare to take decisions and be responsible

k. Honest, humble, simple, and trustworthy

1. Wise and just

m. Discipline

n. Knowledgeable and broad-minded

\section{Decision Making Process of the Female Leader}

Stages or decision-making processes at PPNU-Pi are not entirely carried out by the female leader, but are also carried out by administrators. The decision-making process at PPNU-Pi is still carried out in several stages. The first stage is to identify the problem. Problems that occur in the pesantren will be identified and shared in plenary meetings. Problem identification is made to find out the cause of the problem, where the problem occurs, and what kind of problem is happening. Rivai and Mulyadi $(2013,652)$ convey that making decision-process begins when the social system or organization faces a problem. And the problem is the imbalance between what should be and what is.

The process after identifying the problem is alternative iden- 
tification. Alternative identification is carried out jointly with all levels of the board through a plenary meeting that is scheduled once a month. Each administrator can provide a solution or a way out of a problem that is happening. Rivai $(2013,406)$ explains that alternative identification is the ability to obtain as many relevant alternatives as possible. After getting some solutions from the plenary results, some management will convey to the female leader about the problems that occur and several alternative solutions that have been made at the plenary meeting. Here there is a discussion between the management and the female leader to determine which alternatives are more suitable to be applied Rivai $(2013,406)$ determine the priority is to choose among many alternatives and this is the essence of decision making.

Implementation or implementation is the next step after the determination of alternative solutions made between the female leader and administrators. Implementing a solution usually has a trial period over a period of time. This trial period to see whether the solution is applied successfully or not. If there is a discrepancy or the problem is still not resolved, the caretaker together with the female leader, will return to look for other alternatives. The trial period also provides benefits for evaluating the results of implementing the solution. Rivai $(2013,655)$ explains that the evaluation of results is to assess the process and results of the implementation of the decision, whether it is as expected and make corrections in application if necessary.

\section{Transformational Leadership of the Female Leader}

\section{Ideal Influence}

Based on the results of the field research, it has been found that PPNU-Pi female leader is a leader who has charisma so that the female leader is respected and obeyed by her students. In 
addition, the female leader also becomes a role model of moral goodness. The situation in the field is in accordance with the opinion expressed by Peter G Northouse (2013, 151). He explains that the ideal influence can also be said as charisma or influence ideal. The ideal influence is the emotional component of leadership. The influence ideal describes leaders who act as strong role models for followers.

Another opinion was also conveyed by Robbins and Judge $(2008,91)$ they stated, that the ideal influence in transformational leadership is the behavior of leaders who provide vision and mission, generate a sense of pride, and gain respect and trust from subordinates. They also stated that the ideal influence is also called charismatic, where followers have deep faith in their leaders, feel proud to work with their leaders and trust the capacity of their leaders in overcoming every problem.

\section{Inspiring Motivation}

In this inspirational, motivational aspect, leaders can provide positive motivations, can express essential goals to subordinates and create efforts that can encourage subordinates to achieve organizational goals. The results of the field study found that the female leader of PPNU-Pi could motivate their students to carry out the management mandate and communicates the important objectives of the Islamic boarding school to be achieved.

The situation in the field is in line with the opinion expressed by Wirawan $(2013,141)$. He argues that inspirational motivation in transformational leadership is that leaders can create a clear picture of the future state (goals) that can optimally be achieved and can increase the expectations of the followers for that purpose. Another opinion was also conveyed by Robbins and Judge $(2008,91)$ which stated that inspirational motivation is the behavior of leaders who can communicate high expectations, convey common goals by attracting and inspiring subor- 
dinates to achieve goals that produce progress for the organization.

Bass and Riggio $(2006,6-7)$ state that inspirational motivation is to behave by motivating and inspiring those around them by giving meaning and challenges to work. Team spirit is stimulated, enthusiasm and optimism will be displayed. Leaders will get followers who are actively involved with communication patterns intense and show commitment to shared goals.

\section{Intellectual stimulation}

In this aspect of intellectual stimulation the leader will try to look for new ideas and new ways of doing things. Leaders also provide stimulus and encouragement to followers to be able to be creative and innovate in carrying out their duties. The results of research in the field show that in carrying out its leadership, the female leader of PPNU-Pi are always looking for new ideas, new ideas, or alternative ways, especially in making policies and finding solutions in dealing with problems that occur in pesantren. Fhe female leader also involves administrators and students to contribute to the development of new ideas and creative solutions.

The results of the study are in accordance with the theory stated by Wirawan $(2013,141)$, which states that intellectual stimulation is a leader providing stimulation to his followers to be creative and innovative. The leader encourages his followers to use their imagination and to challenge how to do something acceptable to the social system. A similar opinion was also conveyed by Robbins and Judge $(2008,91)$ which stated that intellectual stimulation is the behavior of leaders who can increase the intelligence of subordinates to enhance their creativity and innovation, increase rationality, and careful problem-solving.

Opinions from others namely from Bass and Riggio (2006, 6-7) they state intellectual stimulation on transformational lead- 
ers is to encourage the efforts of their followers to be innovative and creative by questioning assumptions, reframing problems, and approaching situations in new ways. Creativity is encouraged. There is no public criticism of the individual mistakes of its members. New ideas and creative problem solutions are collected from followers, including in the process of overcoming problems and finding solutions.

\section{Individual Considerations}

The figure of the female leader is someone who has the attention and affection for his students. The female leader tries to provide good quality education and be useful for their students. The female leader has been very supportive of positive activities that benefit students and events that can build the spirit of students. This matter is in line with the opinions of several experts, based on the opinion of Garry Yukl $(2015,317)$ individual considerations include providing support, encouragement, and training for followers. The leader will try to understand the status, position, and expectations of members well. The leader gives personal attention to the members he leads.

Robbins and Judge $(2008,91)$ also argue that individual consideration is the behavior of leaders who give personal attention, treat subordinates individually as individuals with different needs, abilities, and aspirations, train and give advice, and treat each follower as individuals and accompany them, monitor and grow opportunities.

Opinions from Bass and Riggio $(2006,6-7)$ transformational leaders pay special attention to the needs of each follower for achievement and growth by acting as a coach or mentor. The leader listens more to his followers. Delegation of tasks as a means to develop delegated tasks is done by monitoring whether followers need direction or support and assessment progress.

Based on the opinions of the experts above it can be conclud- 
ed, that leaders who have individual considerations are leaders who can provide encouragement, direction, advice or input, and provide training as a form of learning opportunities for followers. It was found in the field, that the female leader of PPNU-Pi had the criteria stated by some of the experts above. The female leader always provides encouragement or motivation for their students to continue to strive to achieve what is expected, so that students can remain disciplined in learning and memorizing the Koran, as well as giving awards to students who excel. The female leader also guides students to be more targeted and not break the rules.

\section{Conclusion}

Based on the results of research conducted in the field, it can be concluded as follows. The female leader at PPNU-Pi has a firm, caring, intelligent, straightforward, communicative and optimistic nature. The decision-making process at PPNU-Pi begins with identifying the problem, followed by finding alternative solutions, then selecting alternatives together with the female leader, followed by applying the solution. After applying the solution, there is a trial period to find out how effective the solution has been implemented. The implementation of female leader's leadership in PPNU-Pi applies important characteristics in transformational leadership, which include ideal influence, inspirational motivation, intellectual stimulation, individual consideration. So, the results of research that states women tend to be transformational are also evident in PPNU-Pi.

\section{Bibliography}

Bass, Bernard M., and Ronald E. Riggio. 2006. Transformational Leadership. Psychology press.

Faraz, Nahiyah Jaidi. 2013. “Kepemimpinan Transformasional." presented at the Diskusi Terbatas, Universitas Negeri Yogyakarta. 
Fauzia, Amelia. 2004. Tentang Perempuan Islam: Wacana Dan Gerakan. Jakarta: Gramedia Pustaka Utama.

Gary A. Yukl. 2015. Kepemimpinan Dalam Organisasi. VII. Jakarta: Indeks.

Ghufron, M. Nur, and Rini Risnawita. 2011. Teori-Teori Psikologi. Yogyakarta: Ar-Ruzz Media.

Hermino, Agustinus Hermino Superma. 2014. Kepemimpinan Pendidikan Di Era Globalisasi. Yogyakarta: Pustaka Pelajar.

Klenke, Karin. 2017. Women in Leadership: Contextual Dynamics and Boundaries. Emerald Group Publishing.

Narwanti, Sri. 2012. Pendidikan Karakter Pengintegrasian 18 Nilai Pembentuk Karakter Dalam Mata Pelajaran. Yogyakarta: Familia.

Nawawi, Hadari. 1998. Administrasi Pendidikan. Jakarta: CV. Haji Masagung.

Northouse, Peter G. 2013. Kepemimpinan Teori Dan Praktek. Jakarta: Indeks.

Rivai, Veithzal, and Deddy Mulyadi. 2013. Kepemimpinan Dan Perilaku Organisasi. Jakarta: Raja Grafindo Persada.

Robbins, Stephen P., and Timothy A. Judge. 2008. "Perilaku Organisasi (Organizational Behavior).” Jakarta: Salemba Empat.

Samani, Muchlas, and Hariyanto. 2012. Pendidikan Karakter. Bandung: PT Remaja Rosdakarya.

Srimulyani, Eka. 2012. Women From Traditional Islamic Education Institutions In Indonesia Negotiating Public Spaces. Vol. 8. Amsterdam: Amsterdam University Press.

Sudaryono. 2014. Budaya \& Perilaku Organisasi. Tanggerang: Penerbit Lentera Ilmu Cendikia. 
Suharsaputra, Uhar. 2012. Kepemimpinan Pendidikan Di Era Globalisasi. Celebon: Pustaka Pelajar.

Sukmadinata, Nana Syaodih. 2013. Metode Penelitian Pendidikan. Bandung: Rosdakarya.

Turney, Mary Ann, and James C. Bishop. 2004. "Women's Learning and Leadership Styles: Implications for Air Crews." Tapping Diverse Talents in Aviation: Culture, Gender, and Diversity, 61-75.

Wijaya, I. Komang Prawina, and Made Surya Putra. 2014. "Pengaruh Kepemimpinan Transaksional Dan Stres Kerja Terhadap Kepuasan Kerja Karyawan PT. Panca Dewata Denpasar, Bali.” E-Jurnal Manajemen 3 (10).

Wirawan. 2013. Kepemimpinan: Teori, Psikologi, Perilaku Organisasi, Aplikasi Dan Penelitian. Jakarta: Rajawali Press. 
This page intentionally left blank 